\title{
Development of new supramolecular nanostructured materials based on peptide hydrogelator Ac-L-Phe-L-Phe-L-Ala-NH2 with embedded liposomes for potential biomedical application
}

\author{
Ruža Frkanec ${ }^{1}$, Karmen Radošević ${ }^{2}$, Adela Štimac ${ }^{1}$, Lucija Horvat ${ }^{3}$, Leo Frkanec ${ }^{4}$ \\ ${ }^{1}$ University of Zagreb,Centre for Research and Knowledge Transfer in Biotechnology, Croatia \\ ${ }^{2}$ Departmentof Biotechnology, University of Rijeka, Croatia \\ ${ }^{3}$ Division of Molecular Biology, Ruder Boškovic Institute, Croatia \\ ${ }^{4}$ Departmentof Organic Chemistry and Biochemistry, Ruder Bošković Institute, Croatia
}

https://doi.org/10.17952/35EPS.2018.148

In recent years design and synthesis of self-assembled nanomaterials with diversified structures and functionalities via fine tuning of supramolecular building blocks increased rapidly.[1] Self-assembling peptides have been widely recognized as nanomaterials with high potential for an extensive range of biomedical applications from drug delivery to tissue enginering, owing to their hydrophilic character and biocompatibility.[2,3]

Short peptide hydrogels made of two or three amino acids are of particular interest because they are cost effective and simple to prepare. It was previously shown that the newly developed self-assembling tripeptide hydrogel Ac-L-Phe-L-Phe-L-Ala- $\mathrm{NH}_{2}$ (Ac-F-F-A- $\left.\mathrm{NH}_{2}\right)$ is effective in enhancing cell proliferation and has potential for use in tissue engineering approaches.[4]

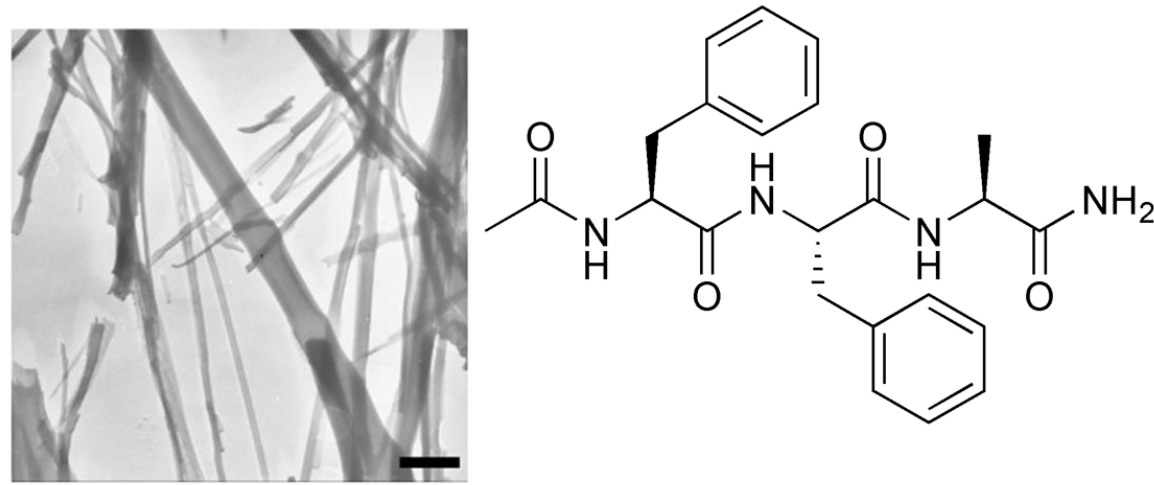

Figure 1: Chemical structure of hydrogelator Ac-L-Phe-L-Phe-L-Ala-NH2. TEM image of hydrogel in water (2.64 mg/ml) PWK-stained. Magnification 8000x, scale bar: $1 \mu \mathrm{m}$.

Ac-L-Phe-L-Phe-L-Ala- $\mathrm{NH}_{2}$ self-assembles at physiological $\mathrm{pH}$ without the need for any organic solvent at a minimum gelation concentration of $0.7 \%, \mathrm{w} / \mathrm{v}$ in saline. The tripeptide derivative contains an aromatic diphenylalanine moiety (Phe-Phe) as a minimalistic building block to drive the self-assembly of short peptides into nanostructures and hydrogels of high stability. Transmission Electron Microscopy (TEM) analysis of the nanofibrous hydrogel network has shown the presence of a mixture of fibers and straight ribbons with diameters in the range of 50-500 $\mathrm{nm}$ and lengths in the range of micrometers, which are stable over weeks at a very low concentration of $2.64 \mathrm{mg} / \mathrm{ml}$ (Figure 1).

The aim of the present study was preparation and characterization of supramolecular systems based on peptide hydrogelator Ac-L-Phe-L-Phe-L-Ala- $\mathrm{NH}_{2}$ and liposomes with incorporated model proteins. The rationale behind preparation of liposomes-in-hydrogel as a delivery system is to assure sustained drug release during their prolonged presence at the administration site.

The gelling properties of the hydrogelator Ac-L-Phe-L-Phe-L-Ala- $\mathrm{NH}_{2}$ with addition of liposomes and model proteins BSA/FITC-BSA were studied. Liposome formulations of BSA and FITC-BSA as well as empty liposomes, incorporated in the hydrogel were characterized by electron and confocal microscopy. It is known that intramolecular hydrogen bonding and noncovalent interactions between molecules of hydrogelators are responsible for the formation of the 3D gel network.[5] Therefore, we have tested the structure of the gel network after the addition of different amounts of protein and liposome.

TEM confirmed incorporationof liposomes and protein into the hydrogel (Figure 2) without disruption of the 
gel network. In gel samples with built-in BSA, the gel network preserved integrity, but it was noticed that the gel fibers were thinner Confocal microscopy proved the incorporation of liposome formulations of FITC-BSA in the hydrogel (Figure 3). It was also shown that liposomes do not impair the gel network of hydrogelator at lipid concentrations lower than the gelator concentration(Table 1).
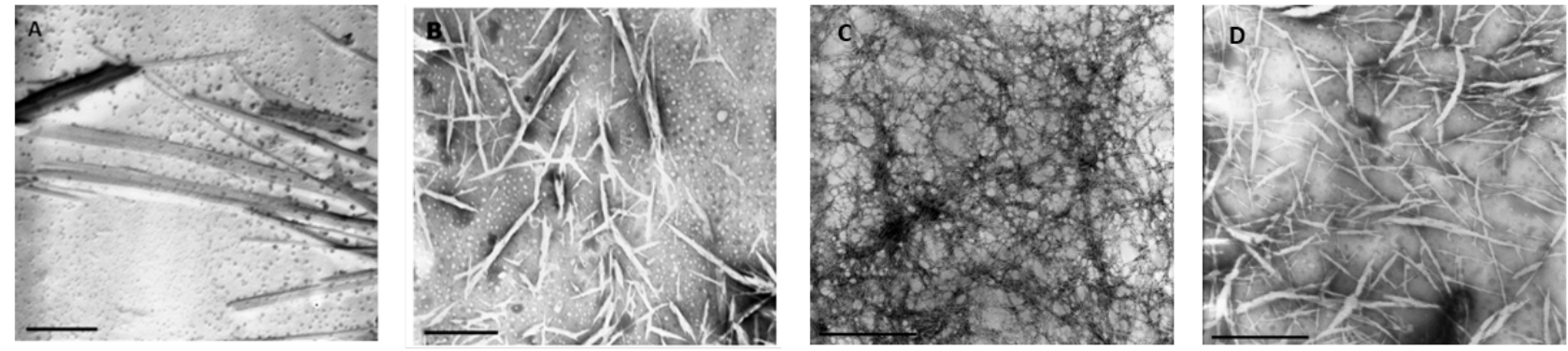

Figure 2: TEM images of (A) liposomes in hydrogel, Pd-shadowed. Lipids:gelator $=1: 2.5,(B)$ liposomes in hydrogel, PWK-stained. Lipids: gelator $=1: 5$. Magnification $10000 x$, scale bar $=1 \mu \mathrm{m},(C) B S A$ incorporated in the gel network (BSA:hydrogel =1:1051), (D) liposome formulation of BSA embedded in gel network (lipids: hydrogel = 1:10), $(C)$ and (D) PWK-stained, Magnification 16 000x. Scale bar: $1 \mu \mathrm{m}$.

Table 1: Gelation of Ac-L-Phe-L-Phe-L-Ala-NH $\mathrm{H}_{2}$ after addition of liposomes.

\begin{tabular}{ccccc|}
$\begin{array}{c}\text { Mass of } \\
\text { hydrogelator } \\
\text { (mg) }\end{array}$ & $\begin{array}{c}\text { Molar ratio } \\
\text { (lipid:gelator) }\end{array}$ & $\begin{array}{c}\text { Lipid } \\
\text { (mg)/mg } \\
\text { gelator }\end{array}$ & Comments \\
\hline 3.6 & $1: 10$ & 0.27 & $\begin{array}{c}\text { Matted, white } \\
\text { gel, quickly } \\
\text { formed }\end{array}$ \\
\hline 3.0 & $1: 5$ & 0.55 & $\begin{array}{c}\text { Matted, white } \\
\text { gel, quickly } \\
\text { formed }\end{array}$ \\
\hline 2.9 & $1: 2.5$ & 1.09 & $\begin{array}{c}\text { Matted, white } \\
\text { gel, quickly } \\
\text { formed }\end{array}$ \\
\hline 3.0 & $1: 1$ & 2.73 & $\begin{array}{c}\text { The gel is not } \\
\text { formed }\end{array}$ \\
\hline
\end{tabular}
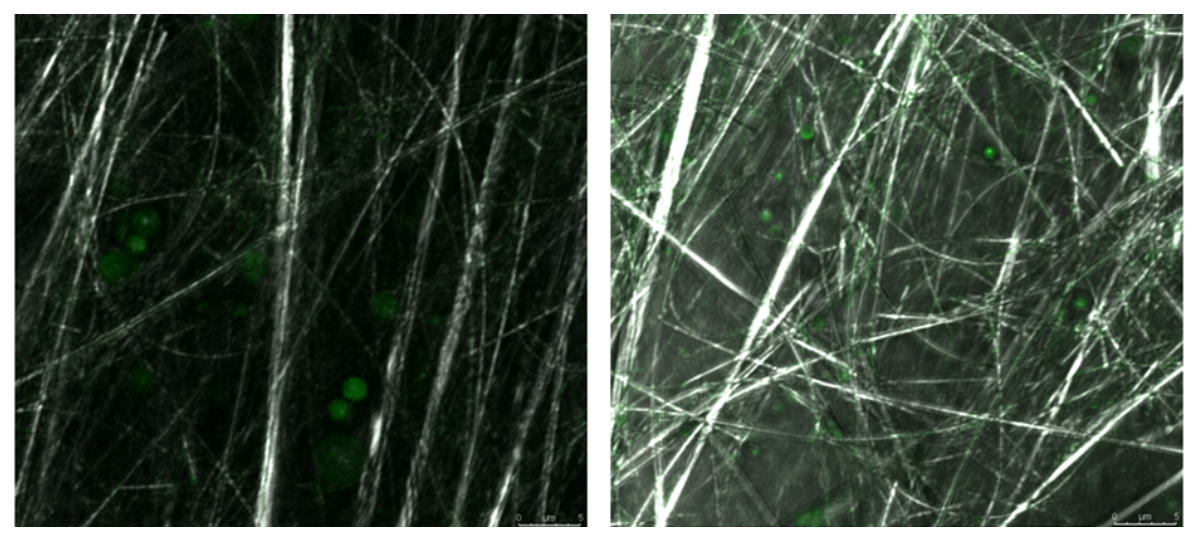

Figure 3: Confocal images of liposome formulation of FITC-BSA embedded in gel network (lipids: hydrogel = 1:10), Pd-shadowed.

We showed that use of higher amounts of protein albumin (BSA)/FITC-BSA resulted in slower gel formation or inability to transition into gel. It was also demonstrated that addition of sufficiently small amount of liposome formulation of BSA and FITC-BSA in hydrogels does not impair the gel network. The described supramolecular 
nanostructured material based on peptide hydrogelator Ac-L-Phe-L-Phe-L-Ala- $\mathrm{NH}_{2}$ with embedded liposomes can be useful in various areas of application in biomedicine, including injections in situ of gelling agents for controlled release of the drug, drug delivery platforms, and tissue engineering.

\section{Acknowledgements}

This work was supported by the grant HRZZ-IP-11-2013-7387 from the Croatian Science Foundation.

\section{References}

1. J. Boekhoven, W. E. Hendriksen, G. J. M. Koper, R. Eelkema, J. H. van Esch, Science 2015, 34, 1075.

2. X. Du, J. Zhou, J. Shi, B. Xu, Chem. Rev. 2015, 115, 13165.

3. R. Dong, Y. Pang, Y. Su, X. Zhu, Biomater. Sci., 2015, 3, 937.

4. T. Pospišil, L. Ferhatović Hamzić, L. Brkić Ahmed, M. Lovrić, S. Gajović, L. Frkanec, Biomater Sci. 2016, 4, 1412.

5. X. Du, J. Zhou, J. Shi and B. Xu, Chem. Rev., 2015, 115,13165. 